\section{THE BRUMMAGEM LIBEL.}

WE should have published the following resolution before, but there appeared to be no necessity for appending to the recent correspondence on the subject any further vindication of Mr. Wood than was contained in the letter of Mr. Ledsam. It is now added, at the wish of some friends of Mr. Wood, with a note, which puzzles us not less than its predecessor, but we take this opportunity of saying that we cannot occupy much space with a debate on questions that were not first raised in this Journal, and may threaten to extend to matters extra muros, which could only be satisfactorily discussed within, among the governors of the hospital.

Birmingham General Hosprtal.-At a meeting of the Medical Board, held Friday, Jan. 13, 1843, it was moved by the Earl of Dartmouth, seconded by Mr. Whateley, and resolved unanimously,-

"That while this board are fully convinced that the deservedly high reputation of Mr. Wood, as a surgical operator, needs no vindication at their hands, they feel bound to mark their strong reprobation of this wanton and scurrilous attack; to declare their nnabated, and, if possible, increased confidence in Mr. Wood's professional skill, and humane attention to the patients under his care; and to express their deep sense of the important services which he has so long rendered, and they trust may long continue to render, to this institution.

$$
\text { (Signed) "WM. Harrold, }
$$

To the Editor.-Sir, In consequence of the communication which appears at p. 715, of THE LANCET, of the 11 th inst., I am preparing a letter, which I hope you will do me the justice to publish in next week's number. Trusting that I shall convince you and your readers that $I$ have neither told a falsehood, nor prevaricated, nor resorted to subterfuge in any shape. I am, Sir, yours respectfully,

Birmingham, Feb. 22nd.

\section{J. J. LeDsam.}

\section{ONE OF THE SLIMY FAMILY.}

\section{To the Editor of The LANCET.}

SIR,-I present to your attention the inclosed circular of Mr. Edwin Edmonds to the St. Columb board of guardians. Many years ago I read the " Ancient Mariner," two lines of which are now in my recollection :-

"And slimy things did crawl with legs Along that slimy sea."

If I have not quoted Coleridge with accuracy, the memories of your readers will easily afford the necessary correction.
Far be it from me to asseverate that amongst the members of the honourable profession of medicine there are any to whom the epithet of " crawling reptile" may be considered appropriate. I am, Sir, your obedient servant,

\section{St. Columb, Cornwall, Feb. 14, 1843.}

\section{J. H. NA NKIVELL.}

"St. Columb, 9th February, 1843.

"Dear Sir,-I hope you will secure my reappointment to the union workhouse, and No. 3 district, by recording your vote in my favour at the approaching election of medical officers for the ensuing year. I take the liberty of asking this favour in consideration of the successful stand $I$ made two years ago (and which I am still ready to make, if required) in coming forward to the aid of the board of guardians, and thus preventing the board from being obliged to submit to that rate of payment dictated to them by the other resident surgeons. I am, dear Sir, your very obedient servant,

\section{"EDwin EDMonds.}

"To Mr. Northey, guardian, St. Columb."

\section{THE STAFFORD MEDICAL- CORONER FUND.}

To the Editor.-Sir: Can you tell me whether Dr. Dehane has handed over to any committee part of the money which he received for withdrawing from the late contest for the coronership of Staffordshire. In his letter to you he expressed his determination to devote whatever balance there might be, after deducting his own expenses, to promote the success of the "next eligible candidate for the office of coroner " and Mr. Nixon, a gentleman of respectability and decision, and who is in every way qualified to exercise the duties of so important an office, is now canvassing the electors of Durham. Under these circumstances, and as no notice on the subject has appeared from Dr. Dehane in your valuable Journal, I consider it my imperative duty, as a bona fide member of the profession, to express, publicly, a hope that the doctor will at once see the propriety of disposing of the balance without delay, and I feel assured that the subscribers of THE LANCET (more particularly those residing in Wolverhampton and its neighbourhood) will be much pleased to peruse a communication from an authorised person acknowledging the receipt of the same for the public purpose to which it was promised to be devoted. I am, Sir, your obcdient servant, February 7, 1843 .

Mena sibi Conscia Recti.

* What attempt has been made to create a fund-which the contribution of Dr. De- 